\title{
A RARE COMPLICATION POTT'S PUFFY TUMOR TREATED WITH FRONTOETHMOIDECTOMY: A CASE REPORT
}

\author{
Muhammad Hamza Ranaa, Muhammad Saleem ${ }^{\mathrm{b}}$
}

aStudent Final Year MBBS Aziz Fatimah Medical \& Dental College Faisalabad.

${ }^{b}$ Associate Professor Department of ENT/Otorhinolaryngology, Aziz Fatimah Trust Hospital Faisalabad.

\begin{abstract}
:
Untreated or undiagnosed frontal sinusitis develops as a subperiosteal abscess in the frontal bone named Pott's puffy tumor (PPT). Pott's puffy tumor is a rare complication that needs surgical excision. In this communication, we report a 50-year-old woman presenting with typical signs and symptoms of PPT. CT-Scan and X-ray imaging are the gold standards to measure the extent of tumor and involvement of structures, if any.
\end{abstract}

KEYWORDS: Pott's puffy tumor, Frontal sinusitis.

https://doi.org/10.37723/jumdc.v12i3.614

How to cite this:

Rana MH, Saleem M. A rare complication pott's puffy tumor treated with frontoethmoidectomy:a case report. Journal of University Medical \& Dental College. 2021;12(3):230-233.https://doi. org/10.37723/jumdc.v12i3.614

This is an Open Access article distributed under the terms of the Creative Commons Attribution License (http://creativecommons.org/licenses/by/4.0), which permits unrestricted use, distribution, and reproduction in any medium provided the original work is properly cited.

\section{INTRODUCTION:}

Sir Percival Pott, in 1760 first described Pott's Puffy Tumor (PPT) ${ }^{[1]}$. A subperiosteally abscess in the frontal bone is associated with osteomyelitis, appearing as the extracranial complication of frontal sinusitis ${ }^{[2,3]}$. Rhinosinusitis is defined as the inflammation of one or more paranasal sinuses. The term rhinosinusitis is preferred over sinusitis because the inflammation of sinus cavities is always accompanied and presented with inflammation of the nasal cavities ${ }^{[4]}$. Careless handling or untreated rhinosinusitis leads to Potts Puffy tumor, which is then surgically excised. According to the literature, advancements in antibiotic medications have significantly reduced the incidence of this rare entity ${ }^{[5]}$. A rare case of a 50-year-old woman reported on October2020 at Aziz Fatimah Hospital, Faisalabad, presented with typical symptoms and presentation of Pott's puffy tumor.

\section{CASE REPORT:}

A 50-Year-Old female presented with repeated complaints of Nasal obstruction, proptosis, and swelling on the forehead in Aziz Fatimah Trust Hospital Faisalabad's outdoor patient department. A brief history revealed that she experienced acute headaches on and off from the past five years associated with frontal head swelling from the past three months. Along with headaches, she also complained of slight visual impairment and nasal blockage (Figure-I). The patient recorded controlled diabetes and hypertension history. Upon general examination, the patient was suffering from left eye proptosis and middle frontal swelling. The patient was hospitalized and underwent surgical resection via frontoethmoidectomy surgery. The imaging technique, CT-Scan, was used to know the extent of tumor swelling (Figure: II-III). Potts Puffy tumor causes bone infection and erosion as a consequence of untreated sinusitis. 
Various etiological factors are responsible for this tumor development due to bacterial infection secondary to the viral penetration. The patient was admitted to the hospital and was given extensive pre-operative medication and broadspectrum antibiotics vertical lynchHowarth incision was made extending from the forehead to the left side of the nasal bridge (Figure-I). After excision of frontal mass $(26 * 20 * 15 \mathrm{~mm})$, the puss was drained, followed by packing. The patient was administered. Histopathology reports revealed inverted papilloma with prominent endophytic growth of interconnected epithelial nests showing high-grade dysplasia. No invasive tumor was noted. The patient was discharged after two days and kept for the follow-up for three weeks, referring the patient to the Oncology Department to Allied Hospital, Faisalabad, for the radiation therapy to avoid reoccurrence. The patient has been prescribed Ceftriaxone as an extensive antibiotic cover to prevent any secondary infection.

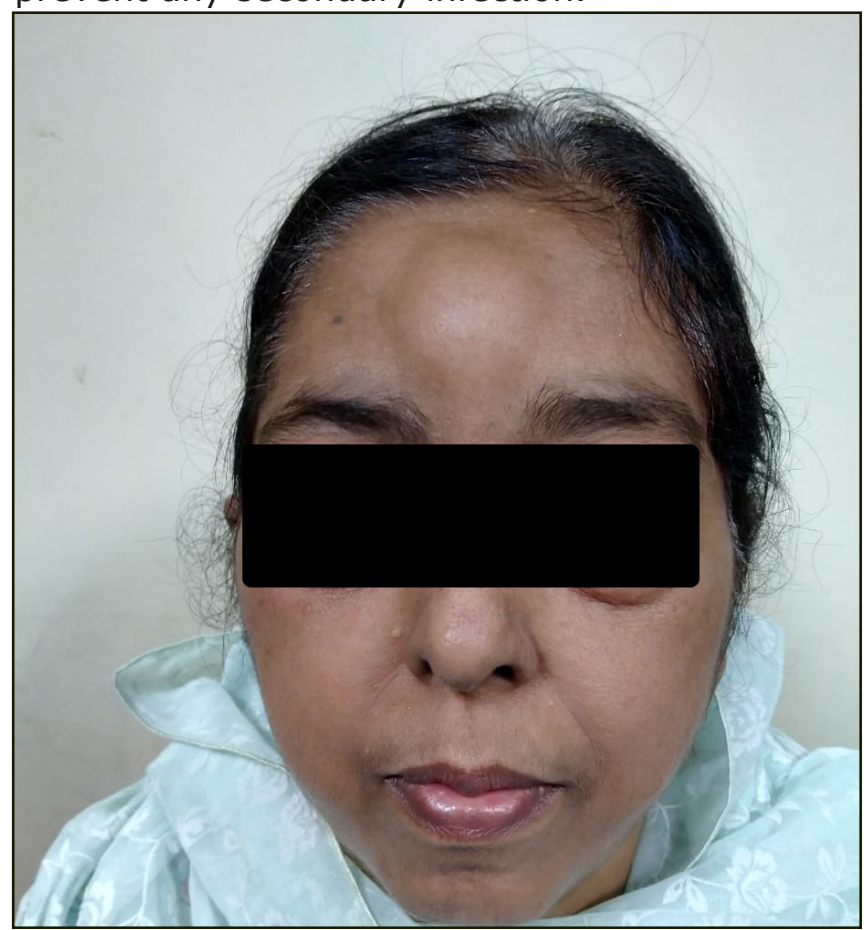

Figure-I: Preoperative view of Large frontal swelling (Frontal view).

\section{DISCUSSION:}

PPT is a rare complication of frontal sinusitis. Untreated or undiagnosed frontal sinusitis can lead to this life-threatening complication.
Frontal sinusitis involves both intra and extra cranial complications. According to studies, it is estimated that about 85 percent of individuals manifest intracranial manifestations ${ }^{[6]}$. Rhinosinusitis refers to the inflammation of nasal and paranasal sinus mucosa[7]. Monosinusitis is prescribed when the inflammation is restricted to only one sinus, most probably maxillary sinuses, and the patient presents with mild to moderate disease.

\section{Corresponding Author:}

Dr. Muhammad Saleem

Associate Professor ENT Department of Otorhinolaryngology, Aziz Fatimah Trust Hospital Faisalabad.

\section{Email:drsaleementspt@gmail.com}

In contrast, the term Pansinusitis indicates the involvement of multiple sinuses, including maxillary, ethmoidal, frontal, and sphenoidal sinuses, and the patient presenting with severe and require emergency otolaryngology neurosurgical emergency interventions. The typical patient presentation of rhinosinusitis includes inflammation, edema, ciliary dysfunction, sneezing, and watery mucus nasal discharge. The etiological of sinusitis involves bacterial, viral, and fungal involvements. Patients with acute disease of viral origin are self-limiting. If only the viral disease persists, bacterial infection supervenes, which is further treated by antibiotic therapy. The most common causative bacterial organism involved in acute disease are Hemophilus influenza, Streptococcus pneumonia, and Moraxella catarrhalis.

In contrast, chronic disease implicates the involvement of S. Aureus, Staphylococcus species, anaerobic gram-negative organisms, and fungi[8]. Sinusitis causes osteomyelitis of the frontal sinus leading to PPT due to direct intracranial spaces. It has a classical presentation of frontal swelling, headache, fever, and purulent rhinorrhea ${ }^{[9,10]}$. High-resolution CT-Scan is the gold standard diagnostic test for PPT that reveals the extent and presence of osteomyelitis, intracranial and intraorbital involvements ${ }^{[10,11]}$. Paranasal sinuses are often complicated by the presence of inverted papillomas, which usually are benign epithelial growths. The pathogenesis reveals allergic etiology, viral infection and chronic prolonged untreated sinusitis. The tumor 

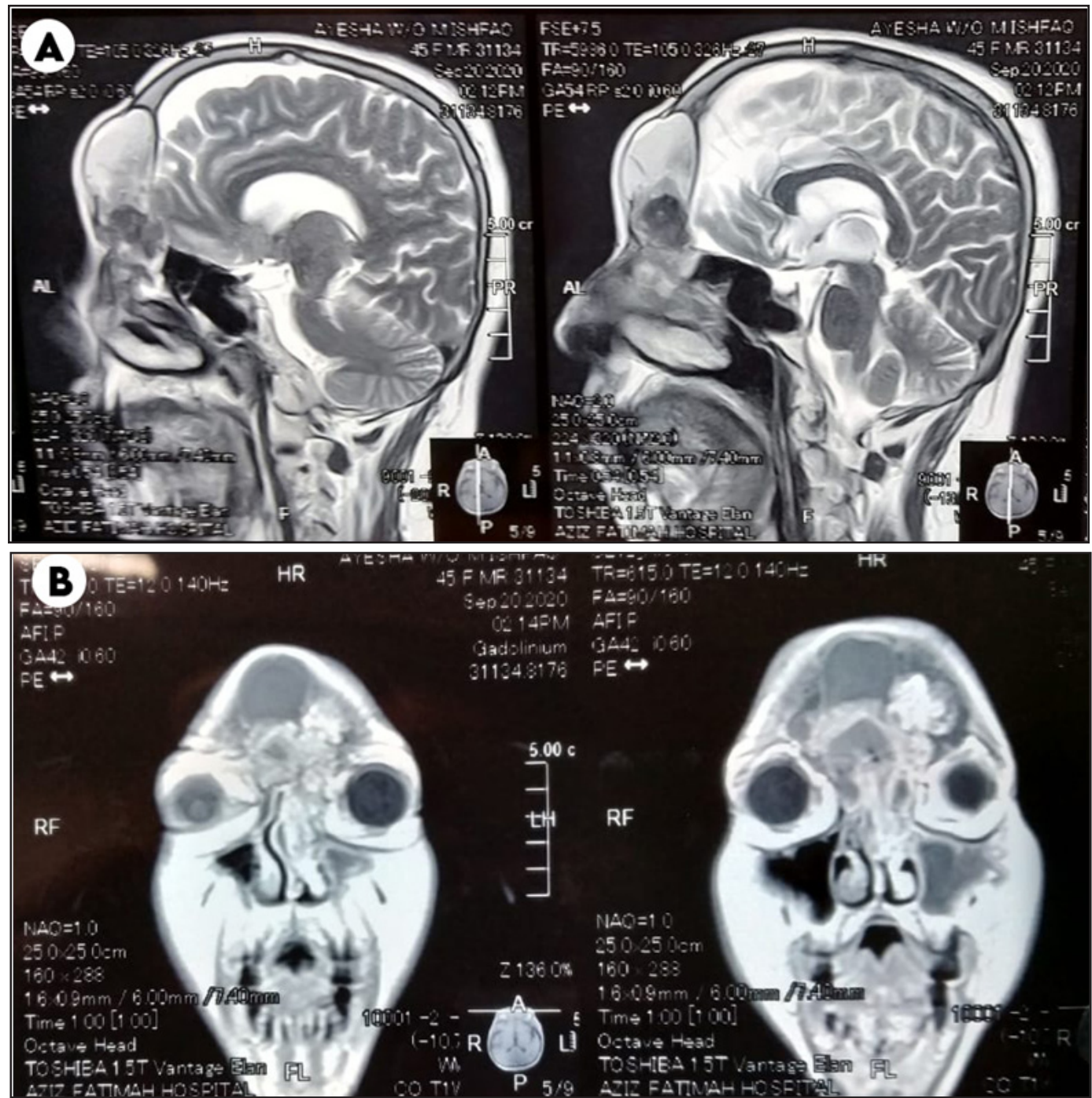

Figure-II: CT scan: (A) Lateral view. (B) Coronal view.

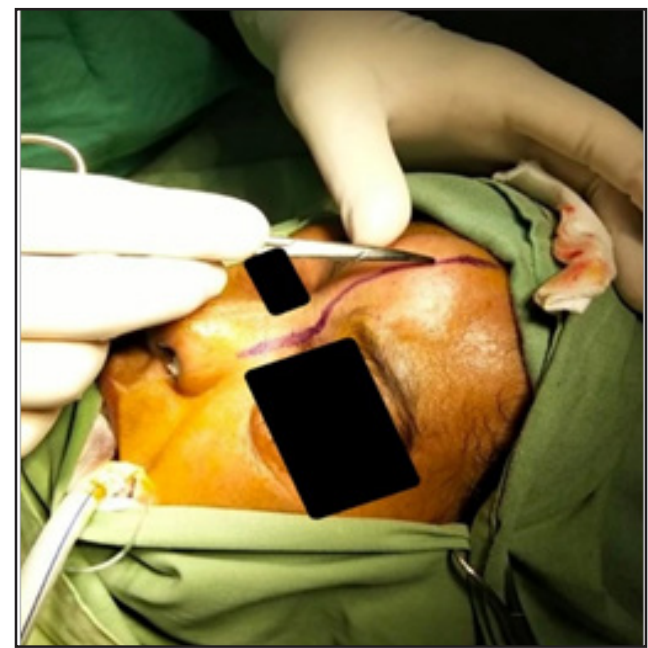

Figure-III: Lynch incision extending from the forehead.

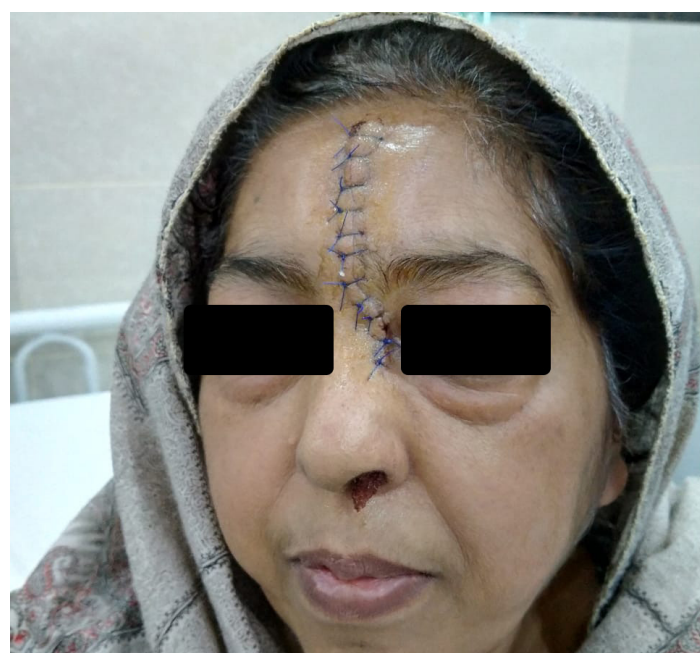

Figure-IV: Post Operative frontal view to the left side of the nasal. 
has a characteristically high recurrence rate with high malignancy potential. The patient is then referred for radiational and chemotherapy ${ }^{[12]}$. Treatment includes both medical and surgical interventions. Medical treatment includes broadspectrum antibiotic therapy for a minimum duration of 6-8 weeks. The surgical approach includes excision and drainage of the tumor swelling and affected areas. Severe complicated cases often require a multidisciplinary approach, including neurosurgeons, ophthalmology, and otorhinolaryngology experts ${ }^{[1,7]}$.

\section{CONCLUSION:}

Pott's puffy tumor is a rare complication and requires surgical excision. The patient suffering from this rare entity generally does not appear ill unless he starts manifesting classic symptoms. However, the patient is advised to follow a complete and comprehensive antibiotic therapy course following surgery to avoid reoccurrence and further complications.

\section{REFERENCES.}

1. Costa L, Mendes Leal L, Vales F, Santos M. Pott's puffy tumor: rare complication of sinusitis . Brazilian Journal of Torhinolaryngol. 2020;86:812-814.Doi: $10.1016 / \mathrm{j}$. bjorl.2016.08.005

2. Vanderveken OM, De Smet K, Dogan-Duyar S, Desimplaere J, Duval EL, De Praeter M, et al. Pott's puffy tumour in a 5-year old boy: the role of ultrasound and contrastenhanced CT imaging; Surgical Case Report. B-ENT. 2012;8(2):127-129.

3. Jung J, Lee HC, Park I-H, Lee H-M. Endoscopic Endonasal Treatment of a Pott's Puffy Tumor. Clinical and Experimental Otorhinolaryngology. $2012 ; 5(2): 112-115$. Doi:10.3342/ceo.2012.5.2.112

4. Kwah JH, Peters AT. Nasal polyps and rhinosinusitis. Allergy Asthma Proceedings. 2019;40(6):380-384. Doi: 10.2500/ aap.2019.40.4252. PMID: 31690375.

5. Salomão JF, Cervante TP, Bellas AR, Boechat MC, Pone SM, Pone MV, et al. Neurosurgical implications of Pott's puffy tumor in children and adolescents. Child's Nervous System. 2014;30(9):1527-1534.

6. Bannon PD, McCormack RF. Pott's puffy tumor and epidural abscess arising from pansinusitis. the Journal of Emergency
Medicine. $2011 ; 41$ ( 6 ): $616-622$. Doi:10.1016/j.jemermed.2008.04.050

7. Bhattacharyya N, Lee LN. Evaluating the diagnosis of chronic rhinosinusitis based on clinical guidelines and endoscopy. Otolaryngology head and neck surgery: official journal of American Academy of Otolaryngology-Head and Neck Surgery. 2010;143(1):147-151. Doi: 10.1016/j. otohns.2010.04.012. PMID: 20620634

8. Kombogiorgas D, Seth R, Athwal R, Modha J, Singh J. Suppurative intracranial complications of sinusitis in adolescence. Single institute experience and review of literature. British Journal of Neurosurgery. 2007;21(6):603609. Doi/10.1080/02688690701552856

9. Haider HR, Mayatepek E, Schaper J, Vogel M. Pott's puffy tumor: a forgotten differntial diagnosis of frontal swelling of the forehead. Journal of Pediatric Surgery. 2012;47(10):1919-1921. Doi:10.1016/j. jpedsurg.2012.06.031

10. Sudhir S. Suppurative Cranial Complications of Sinusitis, Management with Limited Resources: A Report of Two Cases with a Review of the Literature. Journal of Asthma and Allergy. 2017;2(2):1011.

11. Collet S, Grulois V, Eloy P, Rombaux P, Bertrand B. A Pott's puffy tumour as a late complication of a frontal sinus reconstruction: case report and literature review. Rhinology. 2009; 47(4):470-475. Doi:10.4193/Rhin07.060

12. Khandekar S, Dive A, Mishra R, Upadhyaya N. Sinonasal inverted papilloma: A case report and mini review of histopathological features. Journal of Oral \& Maxillofacial Pathology. 2015;19(3):405. Doi: 10.4103/0973-029X. 174644

\section{Author's Contribution:}

Muhammad Hamza Rana: Manuscript writing, literature review.

Muhammad Saleem: Manuscript writing, final approval of the version to be published.

Submitted for Publication: 21-04-2021

Accepted After revision: 20-08-2021 